\title{
Article \\ Modeling of a Grid-Independent Set-Up of a PV/SOFC Micro-CHP System Combined with a Seasonal Energy Storage for Residential Applications
}

\author{
Rahaf S. Ghanem ${ }^{1}$, Laura Nousch ${ }^{2, * \mathbb{D}}$ and Maria Richter ${ }^{2}$ (D) \\ 1 Energy Engineering Department, German Jordanian University, Amman 11118, Jordan; \\ rahafghanim0@gmail.com \\ 2 Fraunhofer IKTS, Fraunhofer Institute for Ceramic Technologies and Systems, 01277 Dresden, Germany; \\ maria.richter@ikts.fraunhofer.de \\ * Correspondence: laura.nousch@ikts.fraunhofer.de; Tel.: +49-351-2553-7235
}

Citation: Ghanem, R.S.; Nousch, L.; Richter, M. Modeling of a Grid-Independent Set-Up of a PV/SOFC Micro-CHP System Combined with a Seasonal Energy Storage for Residential Applications. Energies 2022, 15, 1388. https:// doi.org/10.3390/en15041388

Academic Editor: Orazio Barbera

Received: 20 December 2021

Accepted: 8 February 2022

Published: 14 February 2022

Publisher's Note: MDPI stays neutral with regard to jurisdictional claims in published maps and institutional affiliations.

Copyright: (C) 2022 by the authors. Licensee MDPI, Basel, Switzerland. This article is an open access article distributed under the terms and conditions of the Creative Commons Attribution (CC BY) license (https:// creativecommons.org/licenses/by/ $4.0 /)$.

\begin{abstract}
Renewable energy sources based on solar and wind energy provide clean and efficient energy. The intermittent behaviour of these sources is challenging. At the same time, the needs for efficient, continuous and clean energy sources are increased for serving both electricity and thermal demands for residential buildings. Consequently, complimentary systems are essential in order to ensure a continuous power generation. One of the promising energy sources that helps in reducing $\mathrm{CO}_{2}$ emissions, in addition to providing electrical and thermal energy efficiently, is a Solid Oxide Fuel Cell (SOFC) system operated in a combined heat and power (CHP) mode, due to high electrical efficiencies (in full and part load) and the fuel flexibility. Currently, most studies tend to focus on fuel cell model details with basic information about the building's energy requirements. Nevertheless, a deep understanding of integrating fuel cell micro-CHP systems with renewable energy systems for the residential sector is required. Moreover, it is important to define an operating strategy for the system with a specific controlling method. This helps in evaluating the performance and the efficiency of the building energy system. In this study, an investigation of different configurations of a hybrid power system (HPS) was carried out. The intended aim of this investigation was to optimize a HPS with minimal $\mathrm{CO}_{2}$ emissions, serving the energy demands for a single-family house efficiently and continuously. As a result of this study, a photovoltaic (PV)/SOFC micro-CHP system has satisfied the intended goal, where the $\mathrm{CO}_{2}$ emissions are significantly reduced by $88.6 \%$ compared to conventional systems. The SOFC micro-CHP plant operated as a complimentary back-up generator that serves the energy demands during the absence of the solar energy. Integrating the Power to Gas (PtG) technology leads to a similar emission reduction, while the PtG plant provided a seasonal energy storage. The excess energy produced during summer by the PV system is stored in the fuel storage for a later use (during winter). This SOFC micro-CHP configuration is recommended from an energy and environmental perspective. In terms of feasibility, the costs of SOFC based micro-CHP systems are significantly higher than traditional technologies. However, further technology developments and the effect of economy of scale may cause a substantial drop in costs and the micro-CHP shall become economically competitive and available for residential users; thus, enabling a self-sufficient and efficient energy production on site.
\end{abstract}

Keywords: residential energy systems; hybrid power system; SOFC; power to gas; annual simulation; micro-CHP system; $\mathrm{CO}_{2}$ emissions

\section{Introduction}

The worldwide dilemma in today's increase of energy demand is progressing in parallel with the continued increase of fossil fuels demand such as natural gas (NG), crude oil and coal. The combustion of fossil fuels leads to increased emissions of greenhouse gases and noxious pollutants. 
Renewable energy technologies, such as solar energy systems in its two types, the photovoltaic (PV) and the solar thermal system, helps to overcome the dilemma as they are assumed as efficient, sustainable and eco-friendly technologies. However, several constraints impede the use of renewable technologies for decentralized generation, mainly the fluctuating and intermittent behavior due to the high dependency on weather patterns. Accordingly, significant research efforts were made in the last decade in combining PV systems with backup power generation, energy storage systems, or both.

However, solar-based power generation has seasonal constraints depending on the installation site. Especially in colder countries, the solar power is available during summer times of low energy demand in the household. In winter times, the power and most importantly the heat consumption is much higher.

The above-mentioned constraints can be efficiently overcome by combining fuel cell (FC) systems to renewable energy technologies. In fuel cells, energy is produced by the direct conversion of the chemical energy into both electricity and useful thermal energy (depending on the type of fuel cell). Therefore, fuel cells offer a more efficient and clean way to produce energy compared to conventional power generation technologies. Fuel cell efficiencies are not limited by the Carnot efficiency as for engine-based conversion technologies, which is due to the avoided energy conversion stages towards heat.

Among fuel cells technologies, the Solid Oxide Fuel Cell (SOFC) is a promising technology compared to others, especially for small and medium power applications (up to $1 \mathrm{MW}$ ). The high operating temperature $\left(600-900^{\circ} \mathrm{C}\right)$ in the SOFC allows for the operation using different types of hydrocarbon fuels (e.g., natural gas, biogas, methanol, ammonia) [1-3]. Fueling SOFC systems using natural gas leads to around $54 \%$ reduction in $\mathrm{CO}_{2}$ emissions and the removal of NOx and SOx emissions compared to the traditional fossil fueled energy systems [2]. SOFC systems provide high-temperature exhaust gas that can be utilized for space heating and domestic hot water (DHW) generation in buildings [3]. In addition, for that reason, the SOFC is promising for the residential sector and ideally suited for combined heat and power (CHP) production. By fueling the SOFC with natural gas, an electrical efficiency of $50-60 \%$ is reported, compared to $25-35 \%$ in Polymer Electrolyte Membrane (PEM) fuel cells [4]. In CHP systems, the full potential of the fuel, including the waste heat, is used, providing a high overall efficiency, which is due to the simultaneously generation of heat and electricity [5]. The electricity and heat demand for dwellings can be primarily covered in an efficient way, reducing fuel consumption and $\mathrm{CO}_{2}$ emissions $[5,6]$. Shimoda and Taniguchi [7] compared the use of the cogeneration systems PEM, SOFC and gas engines for different household types in the Japanese residential sector, concluding that SOFC technology can reduce the $\mathrm{CO}_{2}$ emissions significantly due to the possibility for the electricity dominated mode with a high part load capability and efficiency [8].

However, SOFC systems have limited part load capabilities. Due to the high temperatures, the system's dynamics are slow due to the high thermal inertia. Furthermore, thermal cycles cause power degradation in the cells. Therefore, research activities are ongoing that focus on improved operational strategies like the hot standby [9-12] and improved cycle stabilities.

Additionally, the solar energy constraints can be overcome with a new technology, which is power-to-gas (PtG) technology [13]. PtG technology contributes to pass over energy storing challenges of solar energy systems, which occur due to the seasonal differences of the solar radiation. By using the PtG technology, the surplus PV power is converted into a natural gas, which is compatible with the gas grid. The conversion occurs via two steps: $\mathrm{H}_{2}$ production by water electrolysis and methane production by reacting $\mathrm{H}_{2}$ with $\mathrm{CO}$ or $\mathrm{CO}_{2}$ from an external source. By this, a link between the power grid and the natural gas grid can be provided. The resulting $\mathrm{CH}_{4}$ from the methanation process, known as substitute natural gas (SNG), can be injected into the existing gas distribution grid (if available) or into gas storages or be used as fuel cells' fuel. The produced $\mathrm{H}_{2}$ from electrolysis can be directly injected into the gas grid or stored in a special storage without passing through a methanation process. However, the amount of $\mathrm{H}_{2}$ in the gas grid is limited by country spe- 
cific standards and regulations to a maximum of 0-12 vol.\% [14]. Moreover, when it comes to storing the fuel, methane is easier and safer to be stored than hydrogen. It is remarkable that the critical point of hydrogen $\left(\mathrm{p}_{\mathrm{c}}=1.3 \mathrm{MPa}, \mathrm{T}_{\mathrm{c}}=33.1 \mathrm{~K}\right)$ is much lower than the critical point of methane $\left(\mathrm{p}_{\mathrm{c}}=4.6 \mathrm{MPa}, \mathrm{T}_{\mathrm{c}}=190.6 \mathrm{~K}\right)$, and this is the reason behind the linear behavior the hydrogen gas properties with pressure, while it is non-linear for methane gas [14]. Considering the gas compression, compression of hydrogen requires more energy compared to methane since the lower heating value (LHV) is lower $(241.85 \mathrm{MJ} / \mathrm{K}$ mol for hydrogen and 802.34 MJ/K mol for methane) and the required mass flow is higher [14]. Based on a recent report from UK's Institute of Mechanical Engineers, it was presented that the methanation process helps in decarbonization, while the carbon, usually carbon dioxide, is captured from an external source. Therefore, it helps in reducing air pollution and $\mathrm{CO}_{2}$ emissions.

Most early studies, as well as current work, focus on fuel cell model details with basic information of the building energy requirements. However, focusing on the integration of fuel cell micro-CHP systems with renewable energy systems and residential is required. According to that comes the importance of this study, where it takes into consideration the plant and the residential as one object, while it identifies the interaction between the residential and the plant, especially the SOFC micro-CHP. This helps in enhancing the whole system and optimizing a suitable controlling strategy that determines the time of operation for each plant involved in the hybrid power system (HPS) to insure an efficient power generation process. This paper is composed of four sections; in this section, a background has been provided, and related work and the purpose of this study were considered. The methodological approach is described in Section 2. After that, the analysis follows in Section 3, before conclusions are drawn and an outlook is given in Section 4.

\section{Literature Review}

In the regard of combining PV-SOFC systems, different generation technologies are investigated for the residential sector to find the most suitable option concerning high energy efficiency and low $\mathrm{CO}_{2}$ emissions. Sadeghi and Ameri [8] examine a PV/Battery system with different power generation systems, such as SOFC, micro gas turbine, gas generator and diesel generator. In this study, a multi-objective evolutionary algorithm was used to obtain the best solution of the generation system with solar panels and a battery system. The results of this study showed that the SOFC is the most promising power generation technology in the combination with solar panels and a battery. They found that the SOFC has the best economic efficiency, ecological compatibility and reliability.

PEM fuel cells play a role when combined with PV system and electrolyzer. Several studies investigate the coupling of PV systems with PEM fuel cells. Haddad, Ramadan and Khaled [15], for example, analyze coupling parameters for PEM fuel cells, which are the available PV area, the cost of investment and the amount of the produced power. The main drawback using PEM systems is the requirement towards the fuel, which is pure hydrogen in this case. Additionally, Ghnai and Bettayeb [16] present an optimized design and performance of an off-grid PV/PEM/diesel generator power system for a university building. The results of the study based on simulation and performance analysis showed a high renewable fraction of $66.1 \%$ of the proposed stand-alone hybrid renewable power system. In addition to that, the system is economically feasible ( $92 \$ / \mathrm{MWh}$ ) and environmentally friendly ( $\left.24 \mathrm{kgCO}_{2} / \mathrm{MWh}\right)$. In another study [17], the authors proposed a complete self-sufficient hybrid power system comprised of PV, battery storage system and hydrogen fuel cell. They obtained the value of the recommended HPS from an economic perspective. The proposed HPS is accessible for commercial use. However, the initial cost is relatively high because of the high cost of the hydrogen storage tank. Nonetheless, SOFC can also be used in combination with PV system and electrolyzers. The SOFC has a very high electrical efficiency. If operated with pure hydrogen, an electrical efficiency of 52\% are expected. Additionally, SOFC systems simultaneously generate electricity and heat, thus achieving very high overall efficiencies of up to $90 \%$ [4]. This may be important for 
applications in cold countries, thus supplying heating during cold seasons, but also for application in hot countries. Hosseini, Dincer and Rosen [18] suggest a SOFC/electrolysis system, where the produced steam of the SOFC system can be used for an absorption chiller to supply the cooling demand of the house during summer time. In the study of Haddad, Ramadan and Khaled [15], a green energy system is proposed based on coupling a fuel cell either with a PV system or a parabolic trough (PT) solar-thermal system for generating electricity through hydrogen storage and an electrolyzer. Mathematical models were used for PV panels, fuel cells, solar-thermal panels and the electrolyzer. The mathematical models are used to calculate the output power of each system and the produced amount of hydrogen. The selection was made based on different criteria which are: the annual total energy, the most secured system that supplies power greater than the minimum limit or the maximum power during a fixed period, where maximum power is needed for a determined period of time.

Solar energy can be harvested directly as in PV systems or indirectly as in solar thermal systems for generating electricity or for heating/cooling issues. Several studies investigate solar energy systems coupling with fuel cells considering PEM and SOFC.

\section{Materials and Methods}

In this work, the aims of modelling include the estimation of the environmental benefits in terms of $\mathrm{CO}_{2}$ emissions, primary energy savings, operating costs and energy storage capacity reduction. Generally, two main approaches are followed for evaluating energy systems; either a simulation method [5] or an experimental method. A simulation method for a HPS in a domestic application is used in this work, where four different scenarios are evaluated and examined according to the targeted objectives of this work.

Within this section, the used inputs and assumptions for the HPS, such as load profiles, solar radiation data and $\mathrm{CO}_{2}$ emissions formation, are presented in detail. The developed models of the various components which composed the HPS are listed. Then, the control strategy that defines the operation for each integrated plant in the HPS is clarified. The implementation of each simulation scenario is explained in detail as well.

\subsection{Inputs and Assumptions}

\subsubsection{Assumptions}

This section presented the assumed values considered in this study, as shown in Table 1.

Table 1. Assumptions used in this study for several parameters. Abbreviations: photovoltaic (PV), lower heating value (LHV).

\begin{tabular}{cc}
\hline \multicolumn{1}{c}{ Assumptions } \\
\hline PV Panel's Optimal Angle $\left({ }^{\circ}\right)$ & 30 \\
Electrolyzer's Electrical to Fuel Efficiency $(\%)$ & 75 \\
Electrolyzer's Rated Power $(\mathrm{kW})$ & 5 \\
Methanation Process Efficiency $(\%)$ & 82 \\
Methane Heating Value $(\mathrm{MJ} / \mathrm{kg})$ & 50 \\
Hydrogen LHV Enthalpy $(\mathrm{kJ} / \mathrm{mol})$ & -241 \\
Solar-thermal System Efficiency $(\%)$ & 75 \\
\hline
\end{tabular}

\subsubsection{Load Profiles}

The interaction between the building and its energy load profiles is considered in the HPS of this study. A good approximation of how the system is operating is essential in order to be able to model a HPS in any simulation software. Accordingly, the performance of the building on a daily basis, which describes the electricity, space heating and DHW needs, should be defined. In this study, the building's performance is evaluated based on scaled heat and electricity load profiles according to VDI-4655 (Association of German Engineers) reference guidelines [19]. 
VDI-4655 guideline is defined to determine CHP-system's efficiencies that are designed to supply heat and electrical energy for a residential building. The VDI-4655 guideline is developed by forming a reference load profile based on measured data for electrical, space heating and DHW energy consumptions of several single-family houses located in Germany during ten typical day categories, as shown in Table 2. Each reference load profile represents the daily energy consumption in a one-minute average with a cumulative consumption of $1 \mathrm{kWh}$ /day. The mentioned day-type categories are defined according to the air temperature, clouds and whether the considered day is a working day or a holiday [19].

Table 2. Different day-type categories according to VDI-4655 guidelines.

\begin{tabular}{cccccc}
\hline \multirow{2}{*}{ Season } & \multirow{2}{*}{ Air Temperature $\left.{ }^{\circ} \mathbf{C}\right)$} & \multicolumn{3}{c}{ Day Category Abbreviations } \\
\cline { 3 - 6 } & & Working Day & \multicolumn{2}{c}{ Holiday } \\
\cline { 3 - 6 } & & Cloudy & Sunny & Cloudy & Sunny \\
\hline Winter & $T_{\text {Air }}<8.5$ & WWC & WWS & WHC & WHS \\
Transition & $8.5 \leq T_{\text {Air }} \leq 22.8$ & TWC & TWS & THC & THS \\
Summer & $T_{\text {Air }}>22.8$ & \multicolumn{2}{c}{ SWX } & \multicolumn{2}{c}{ SHX } \\
\hline
\end{tabular}

Even though VDI-4655 reference load profiles are generated at German sites, they can be used for the Jordan case since this study is made for a single-family house with similar electrical appliances in the single-family house as in Germany. The difference in energy consumption between the case in Germany and Jordan is noticed by the daily demand (c.f. Table 3), which is due to the difference in the geographical location. In Jordan, more electrical energy is needed during summer due to the use of the cooling systems, while less heat energy is needed during winter times. Table 3 shows the daily electrical and thermal energy demands in different seasons.

Table 3. The daily electrical and thermal energy demands for the single-family house during summer, winter, and transition seasons. Abbreviations: domestic hot water (DHW).

\begin{tabular}{ccccc}
\hline Season & $\begin{array}{c}\text { Number of Days } \\
\text { during the Year }\end{array}$ & $\begin{array}{c}\text { Electrical } \\
\text { Demand } \\
\text { (kWh/Day) }\end{array}$ & $\begin{array}{c}\text { Space Heating } \\
\text { Demand } \\
\text { (kWh/Day) }\end{array}$ & $\begin{array}{c}\text { DHW Demand } \\
\text { (kWh/Day) }\end{array}$ \\
\hline $\begin{array}{c}\text { Summer } \\
\text { Transition }\end{array}$ & 156 & 24 & - & 10 \\
Winter & 71 & 22 & - & 10 \\
\hline
\end{tabular}

Figures 1-3 represent the scaled electricity, space heating and DHW energy load profile for the chosen single-family house of this study. The load profiles are for SHX, THC and WHC day categories, and the presented patterns follow the house activities.

In general, electricity demands are higher during the day times compared to the night times. In summer, the electricity demand is high during the morning, while it shifts to evening hours during winter days. The heat during summer and transition are only required for the DHW, where the peaks are during morning and evening hours, and where the heat demand for space heating during summer and transitions are zero.

The heat and electricity demand data (in hourly time steps) are used as inputs for the simulation models described below. 


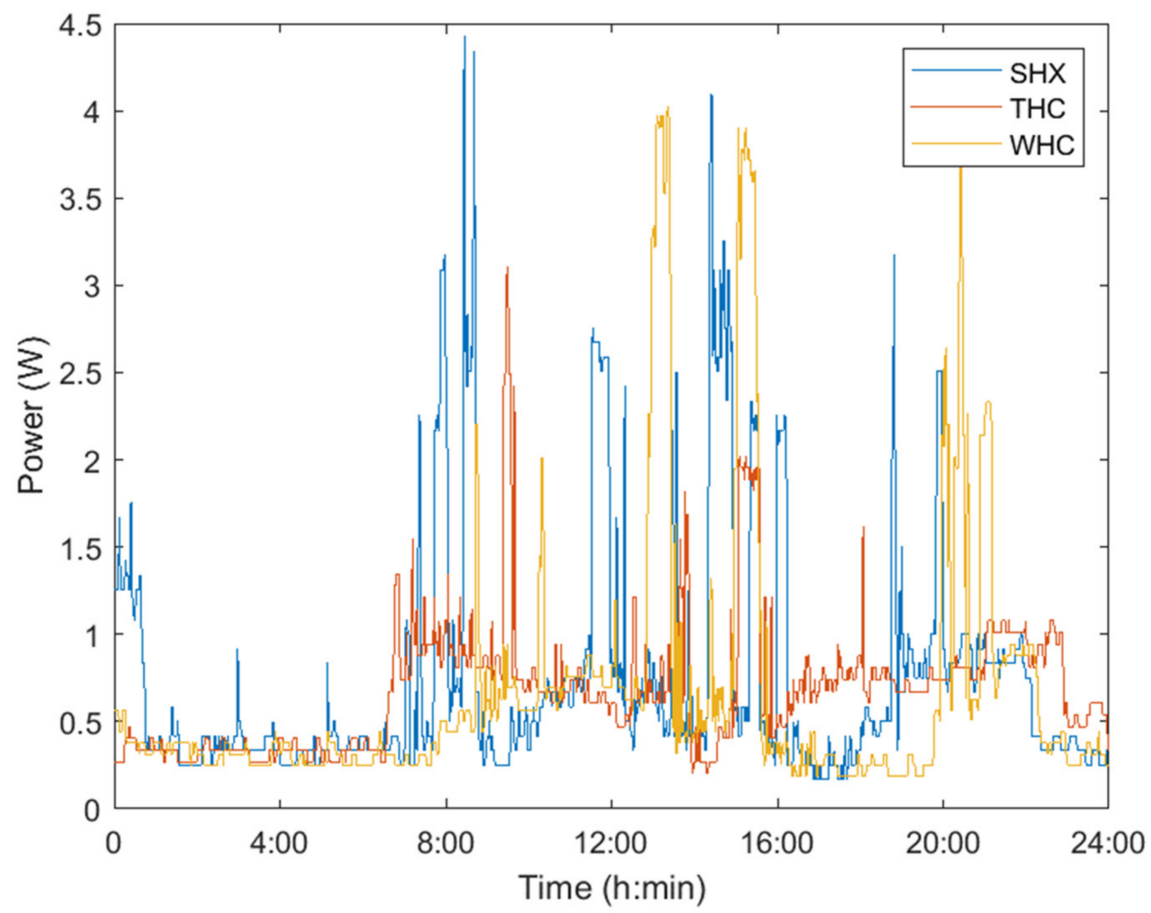

Figure 1. Daily electrical scaled load profile for the single-family house in Jordan during day types SHX, THC and WHC, scaled according to VDI-4655 guidelines.

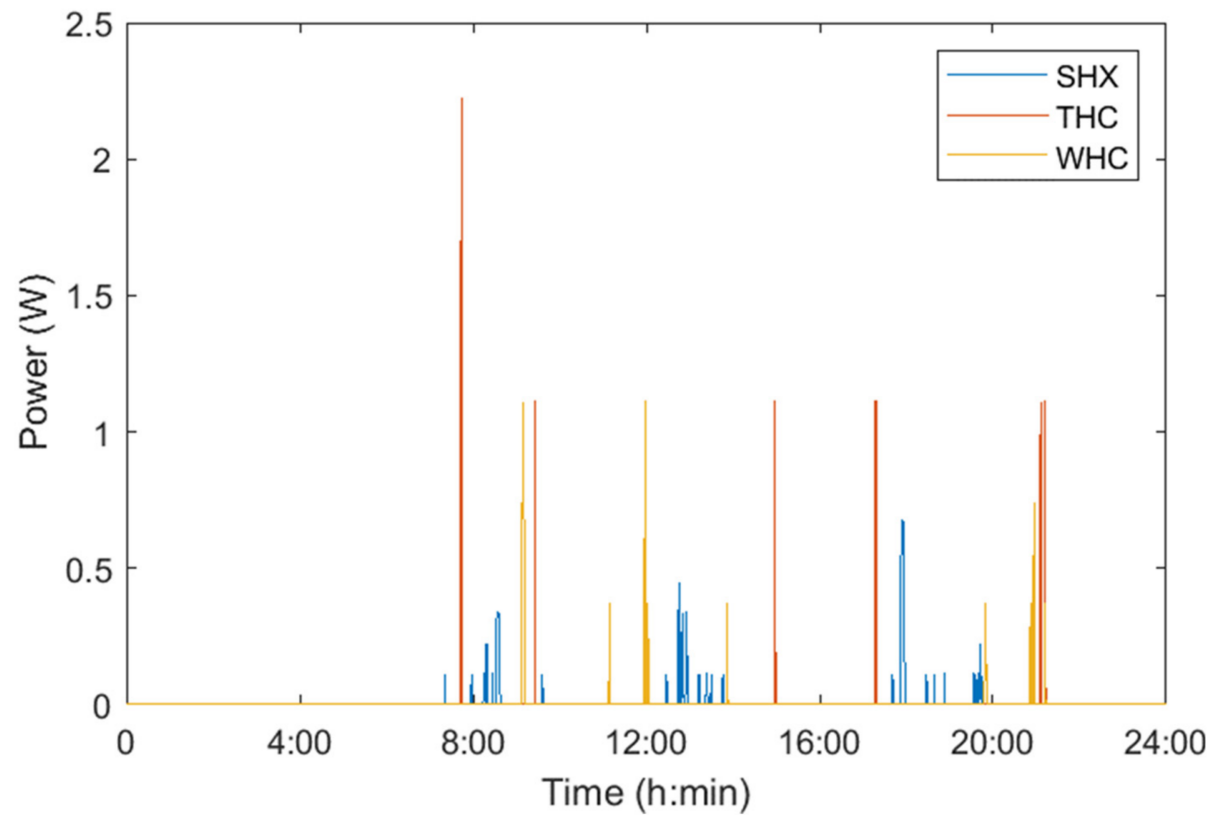

Figure 2. Daily DHW scaled load profile for the single-family house in Jordan during day types SHX, THC and WHC, scaled according to VDI-4655 guidelines. 


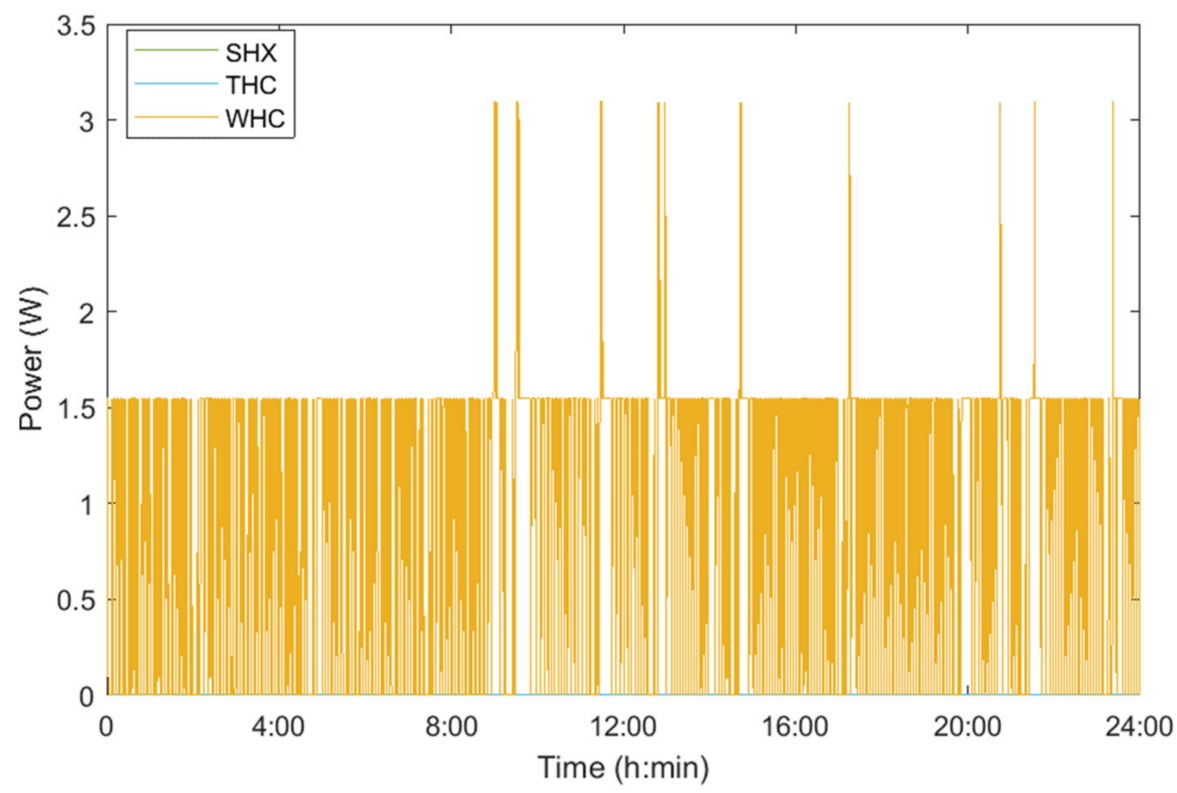

Figure 3. Daily space-heating scaled load profile for the single-family house in Jordan during day types SHX, THC and WHC, scaled according to VDI-4655 guidelines. Space-heating demand during THC and WHC day types is zero.

\subsubsection{Solar Radiation Data}

The solar radiation data is obtained from Photovoltaic Geographical Information System (PVGIS) tools [20]. The data represents a one-year hourly solar radiation of the location with a latitude and longitude of $31^{\circ} 57^{\prime} 47.3688^{\prime \prime} \mathrm{N}$ and $35^{\circ} 55^{\prime} 49.2924^{\prime \prime} \mathrm{E}$ (Amman, Jordan), respectively.

Figure 4 shows the solar radiation data for the location of this study. The annual average of solar radiation is estimated to be $5.9 \mathrm{kWh} /\left(\mathrm{m}^{2}\right.$, day).

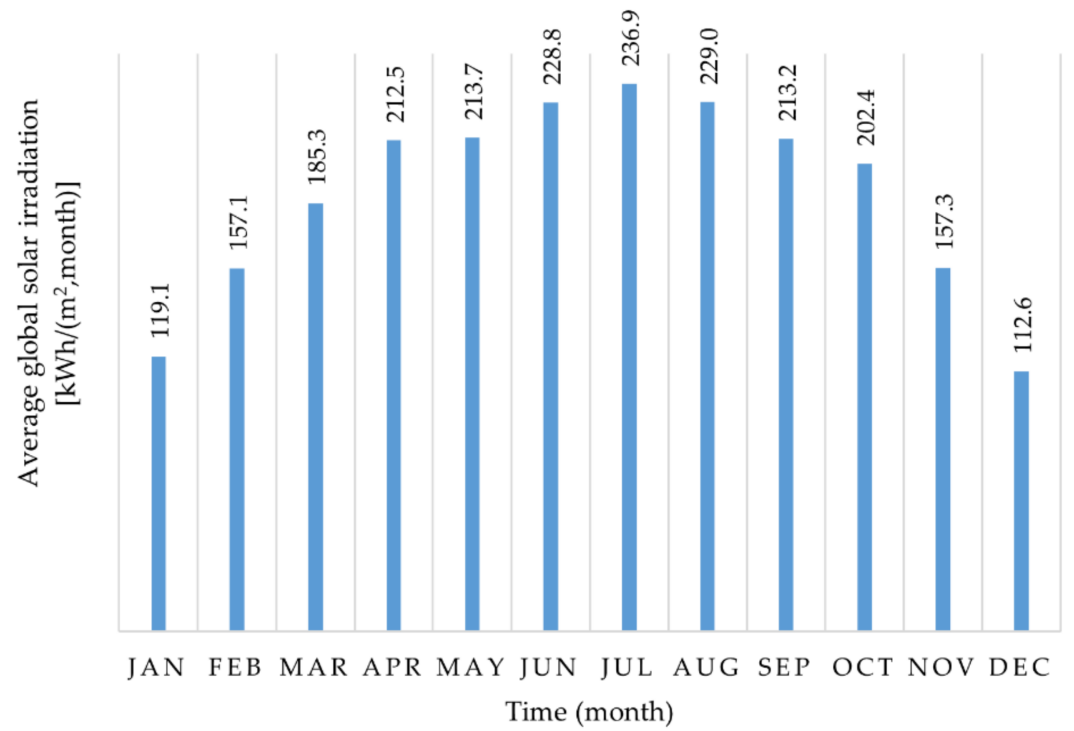

Figure 4. Average monthly global solar irradiation for the selected location with $31^{\circ} 57^{\prime} 47.3688^{\prime \prime} \mathrm{N}$ and $35^{\circ} 55^{\prime} 49.2924^{\prime \prime}$ E latitude and longitude, respectively, obtained from PVGIS. Abbreviations: Photovoltaic Geographical Information System (PVGIS).

It is noticed that solar radiation for the selected location is high during the months of May, June, August and September, while it is the highest during July. In contrast, the solar irradiance is low in January, February, November and December. 


\subsection{4. $\mathrm{CO}_{2}$ Emissions Calculations}

The basic principle is to satisfy heat and electricity demands at all times. Heat demand is covered by the fuel-cell, the solar thermal system, and the diesel heater (DH), while electricity is covered by the fuel cell, the PV system, and the utility-grid. The aim of this study is to minimize the total $\mathrm{CO}_{2}$ emissions $z$ [5] produced from the operation of the house, where the fuel cell, the diesel heater and the utility-grid have the main impact.

$$
z=g_{g} G_{t}+g_{e} E_{t}
$$

where, $G_{t}$ is calculated as follows [5]:

$$
G_{t}=G_{t, F C}+G_{t, D H}=\frac{Q_{t, F C, \text { elec }}}{\eta_{F C, \text { elec }}}+\frac{Q_{t, D H, \text { ther }}}{\eta_{D H}}
$$

The amount of produced $\mathrm{CO}_{2}$ emissions from each source are presented in Table 4 .

Table 4. The amount of the produced $\mathrm{kgCO}_{2}$ from utility-grid, diesel fuel and methane fuel, evaluated for the Jordan case.

\begin{tabular}{cc}
\hline \multicolumn{3}{c}{$\mathrm{CO}_{2}$ Emissions Data } \\
\hline Utility Grid & $0.690 \mathrm{~kg} \mathrm{CO}_{2} / \mathrm{kWh}$ \\
Diesel Fuel & $2.63 \mathrm{~kg} \mathrm{CO}_{2} / \mathrm{L}$ \\
Methane Fuel & $2.7 \mathrm{~kg} \mathrm{CO}_{2} / \mathrm{kgCH}_{4}$ \\
\hline
\end{tabular}

\subsection{Simulation Models in Modelica}

The developed simulation model that combines the HPS simulation and the mathematical modelling is presented in this section. In this study, several submodels are included in the simulation model, such as the building energy model, the micro-CHP SOFC system model, the PV system model, the PtG system model, the solar thermal system model, and the energy storage systems model, as shown in Figure 5.

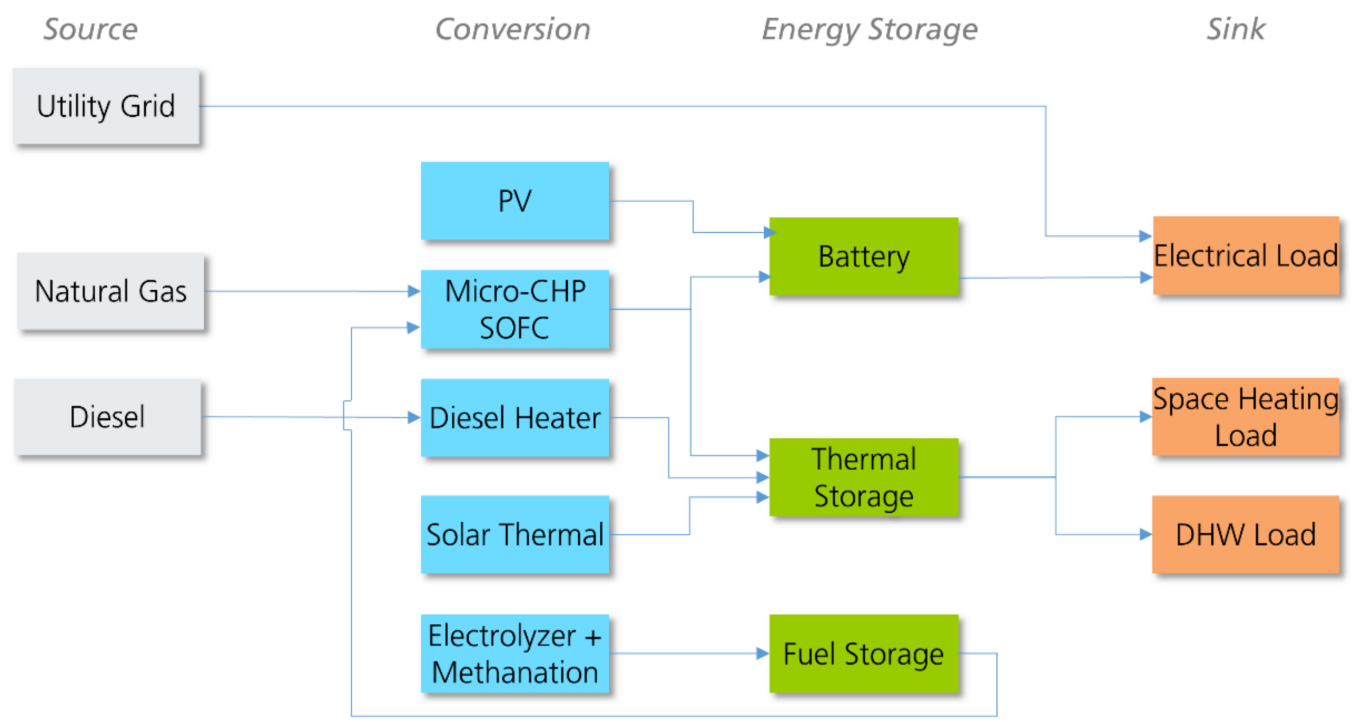

Figure 5. Hybrid power system (HPS) model showing all the integrated components to the system.

\subsubsection{Building Energy Model}

A single-family house is selected in this study and its energy consumption patterns are referred to VDI-4655 guidelines in order to create electricity, DHW and heat demand data for the building (regardless of the used heating system). The generated data represent the required inputs by the heating and electricity systems that are included in the HPS simulation model. 
The selected single-family house located in Amman-Jordan covers a floor area of $180 \mathrm{~m}^{2}$ with two stories and occupied by five persons. In the assumed reference scenario, the used space heating system is a conventional heater fueled by diesel, while the DHW is covered by a solar thermal system. The electricity source is dual for the reference scenario: $50 \%$ is covered by the utility grid and $50 \%$ is covered by a PV system.

\subsubsection{Micro-CHP SOFC System Model}

In this study, the micro-CHP SOFC system is modelled as a power generator fueled with natural gas. The system is modelled as a black box, which converts the fuel energy into electricity and useful heat pursuant to its efficiency. To avoid thermal cycles, a hot standby is assumed for the SOFC system. The operation of the fuel cell is constrained by the minimum and maximum SOC of the battery. The characteristics for the used fuel cell in this study are presented in Table 5.

Table 5. The main characteristics of the modelled fuel cell system.

\begin{tabular}{cc}
\hline \multicolumn{1}{c}{ Fuel Cell Characteristics } \\
Type & SOFC \\
Fuel Type & Methane \\
Rated Power (kW) & 2.5 \\
Electrical Efficiency (\%) & 40 \\
Thermal Efficiency (\%) & 55 \\
Fuel Utilization (\%) & 85 \\
Controller Set Value & Battery SOC \\
SOFC Hot Stand-by Fuel Input (W) & 800 \\
SOFC System Internal Power Consumption $(\mathrm{W})$ & 30 \\
\hline
\end{tabular}

\subsubsection{Photovoltaic System Model}

The PV system is sized considering the available area and the tilt angle of the PVmodule at the selected location. The output power of the PV system is calculated in terms of the direct solar radiation at the selected location and the number of PV-modules [15]. The optimal tilt angle at the selected location is $\theta_{\text {optimal }}=30^{\circ}$.

The used PV module is the simplified model from the Modelica BuildingSystems Library [21], which produces the electrical power $\mathrm{P}_{\text {MPP }}$ for a MPP-controlled PV module, and has the characteristics shown in Table 6.

Table 6. PV-module characteristics according to TSM230PC05 from the Modelica BuildingSystems Library.

\begin{tabular}{cc}
\hline \multicolumn{2}{c}{ PV Module Characteristics } \\
\hline Rated Power $(\mathrm{W})$ & 230 \\
Open Circuit Voltage (V) & 37 \\
Short Circuit Current (A) & 8.26 \\
Dimensions L $\times$ W $(\mathrm{m})$ & $1.65 \times 0.992$ \\
\hline
\end{tabular}

\subsubsection{PtG System Model}

In the PtG process, the surplus power is converted into gas, providing a link between the power grid and the gas grid. This conversion occurs via two steps: $\mathrm{H}_{2}$ production by water splitting into $\mathrm{H}_{2}$ and $\mathrm{O}_{2}$, and methane production by reacting $\mathrm{H}_{2}$ with $\mathrm{CO}$ or $\mathrm{CO}_{2}$, which may result from the SOFC flue gas, as assumed in this study.

- $\quad$ Electrolyzer

The electrolyzer is sized based on the maximum DC power generated by the PV system in June (the highest solar radiation in Amman), adding to it $20 \%$ as a reserved capacity. The model of the electrolyzer is represented as a black box that converts the surplus electrical 
energy into fuel energy based on its efficiency. The efficiency of the electrolyzer is calculated as follows [22]:

$$
\eta_{E Z}=\frac{\Delta H_{L H V_{\mathrm{H} 2}}}{U_{c e l l}}=\frac{1.25 \mathrm{~V}}{U_{c e l l}}
$$

The $\mathrm{H}_{2}$ mass flow rate produced by electrolysis is calculated as follows [23]:

$$
m_{\mathrm{H}_{2}}=\frac{P_{E Z} \eta_{E Z}}{H H V_{\mathrm{H}_{2}}}
$$

The operation of the electrolyzer is constrained by the maximum SOC of the battery as the priority is to fully charge the battery. The used type of electrolyzer in this study is the polymer electrolyte membrane electrolyzer (PEME) with an electrical-to-fuel efficiency of $75 \%$ [24] and $5 \mathrm{~kW}$ rated power. The PEME has a quick start-up time that ranges from seconds to minutes [24] compared to the other types. The quick start up time allows a quick response for converting the surplus energy produced by the PV system without any delays. Using the SOFC in the reversible mode for electrolysis would be another option, which is neglected here due to the lack of technology maturity. As for today, long-term stable reversible Solid Oxide Cells (rSOC) systems are not available yet, but might be considered in future research.

- Methanation Process

The methanation process is modelled based on the given chemical reaction.

$$
4 \mathrm{H}_{2}+\mathrm{CO}_{2} \stackrel{\text { yields }}{\rightarrow} \mathrm{CH}_{4}+2 \mathrm{H}_{2} \mathrm{O}
$$

The above chemical reaction indicates that each $1 \mathrm{~kg}$ of the produced $\mathrm{H}_{2}$ by electrolysis needs around $5 \mathrm{~kg}$ of $\mathrm{CO}_{2}$ to form $2 \mathrm{~kg}$ of $\mathrm{CH}_{4}$. The formed $\mathrm{CH}_{4}$ can be stored in the fuel storage to operate the fuel cell during the absence of the solar radiation. In this study, the considered methanation process is biological methanation (BM) with a hydrogen-to-fuel efficiency of $78 \%$ according to the reference [13].

\subsubsection{Solar Thermal System Model}

In this work, the solar thermal system is modelled as a unit that converts the solar power into thermal energy according to the solar radiation, the efficiency of the system and the total area of the system. As in the PV system model, the solar radiation data is obtained from the PVGIS at the location of the study and is used as an input for the solar thermal system. The efficiency of the solar thermal system is set to $75 \%$.

\subsubsection{Energy Storage System Model}

Due to the intermittent behavior of the PV system and the solar thermal system, energy storages are essential to meet the load demand at night and during the low solar radiation. Different types of energy storages are integrated to the HPS model in this study: thermal storage, fuel storage and battery.

- Thermal Storage

In this work, the thermal storage model is represented by a hot water storage tank that is characterized based on the volume and energy content. The model is controlled by the maximum energy content and the energy flowing from the plant to the storage and from the storage to the single-family house. For the HPS in this study, the energy content of the thermal storage should serve both the space heating and the DHW demand. The heat energy required to maintain the storage temperature at $60^{\circ} \mathrm{C}$ is calculated as follows [25]:

$$
q=m c_{p} \Delta T
$$




\section{- Fuel Storage}

Similar to the thermal storage, the model of the fuel storage is represented by a special storage tank characterized by the volume and the energy content. This storage is used to store the produced methane from the PtG process. The fuel should be stored under certain conditions in order to ensure a long-term and a safe storing process (pressure and temperature). The storage is controlled by the maximum energy content, the heating value of methane fuel (50 MJ $/ \mathrm{kg}$ ), and the flow of energy from the PtG plant to the storage and from the storage to the SOFC plant.

\section{- Battery}

For the defined HPS, the battery bank is used as a backup device to overcome the weakness of the SOFC that has a slow dynamic response during sudden peak demands. The battery is also used to store the excess electrical power produced by the PV system. In this work, the battery bank simulation model calculates the actual state of charge (SOC) as follows [26]:

$$
\mathrm{SOC}=100\left(1+\frac{\int I_{D} d t}{C}\right)
$$

The available battery capacity is controlled by its maximum $P_{C}$, max and minimum $P_{C, \min }$ charging power and given as follows [26]:

$$
\begin{gathered}
P_{C, \min } \leq \mathrm{SOC} \leq P_{C, \max } \\
\mathrm{SOC}=(1-\mathrm{DOD})
\end{gathered}
$$

where DOD is the depth of discharge for the battery bank. The discharging power $P_{D}$ of the battery is constrained by the maximum hourly discharging power $P_{D, \text { max }}$ and given as [16]:

$$
0 \leq P_{D} \leq P_{D, \max }
$$

\subsection{Control Strategy}

Two different proposed algorithms are used in the HPS of this study to indicate which subsystem is operating at each time step. The first algorithm is used to control the electrical part of the HPS and the controller is the battery bank. The second algorithm is used to control the thermal part of the HPS and the controller is the thermal storage. Figures 6 and 7 represent the flow charts of the proposed algorithms for the battery and the thermal storage.

\subsection{Simulation Scenarios}

In this study, four different simulation scenarios are modelled, as presented in Table 7. In each scenario, a plant is added/removed from the HPS model. All simulation scenarios are analyzed for a full year and for the proposed ten day-type categories mentioned in Section 2.1.2. Later, these scenarios are compared regarding the $\mathrm{CO}_{2}$ emissions of the HPS, the capacity of the energy storages and the required land area. Exemplarily, Figure 8 represents a simplified schema of Scenario 4.

Scenario 1 refers to the reference system used in the single-family house; $50 \%$ of the electricity is served by the PV system and $50 \%$ by the utility grid, while the space heating demand is covered by the diesel heater and the DHW is served by the solar thermal system. Scenario 1 is taken as a reference for evaluating the other Scenarios (2, 3 and 4). Scenario 1 is optimized in Scenario 2 in terms of reducing the $\mathrm{CO}_{2}$ emissions, where both the utility grid and the diesel heater are eliminated. Scenario 3 is then optimized in terms of the total land area by adding the SOFC micro-CHP system. The inclusion of the SOFC system in Scenario 3 causes a reduction in the required capacities of both the PV system and the solar thermal system since now it is covering part of the thermal and electrical demands. Scenario 4 is an optimization of Scenario 3 in terms of offering a seasonal energy storage and a reduction in the $\mathrm{CO}_{2}$ by integrating the PtG technology to the HPS. 
$\mathrm{P}_{\mathrm{N} . . .}$ Net Power

$\mathrm{P}_{\mathrm{P} . . .}$. Produced Power

$P_{L}$...Load Power

$\mathrm{P}_{\mathrm{C}}$...Charging Power

$P_{D}$...Discharge Power

$P_{G} \ldots$ Grid Power
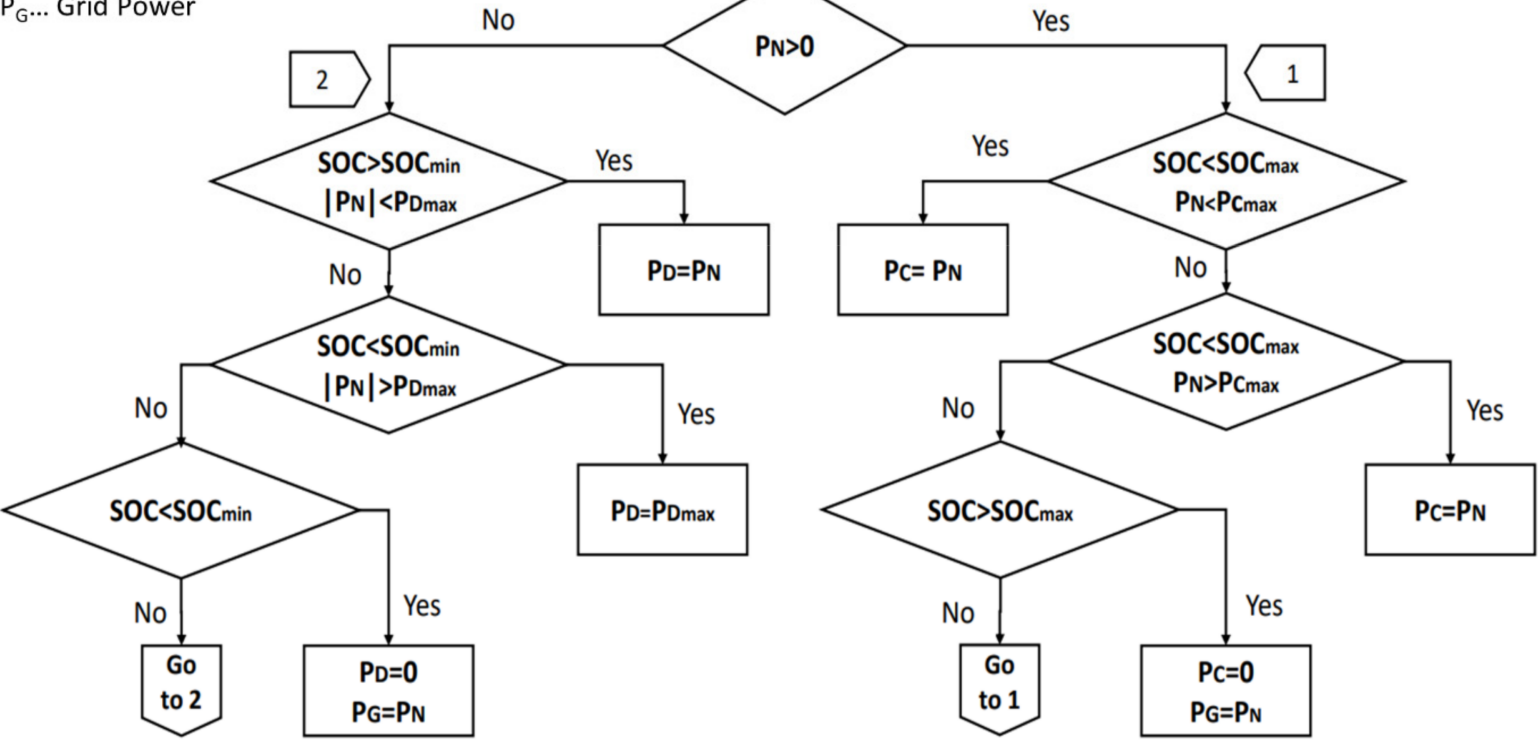

Figure 6. Flow chart of the proposed algorithm for the electrical part of the HPS controlled by the battery bank.

$Q_{N}$. Net HeatPower

$Q_{p}$... Produced Heat Power

$Q_{L} \ldots$ Load Heat Power

$\mathrm{Q}_{\mathrm{C}}$...Charging Heat Power

$\mathrm{Q}_{\mathrm{D}}$...Discharge Heat Power

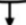

$=\mathrm{PP}-\mathrm{PL}$

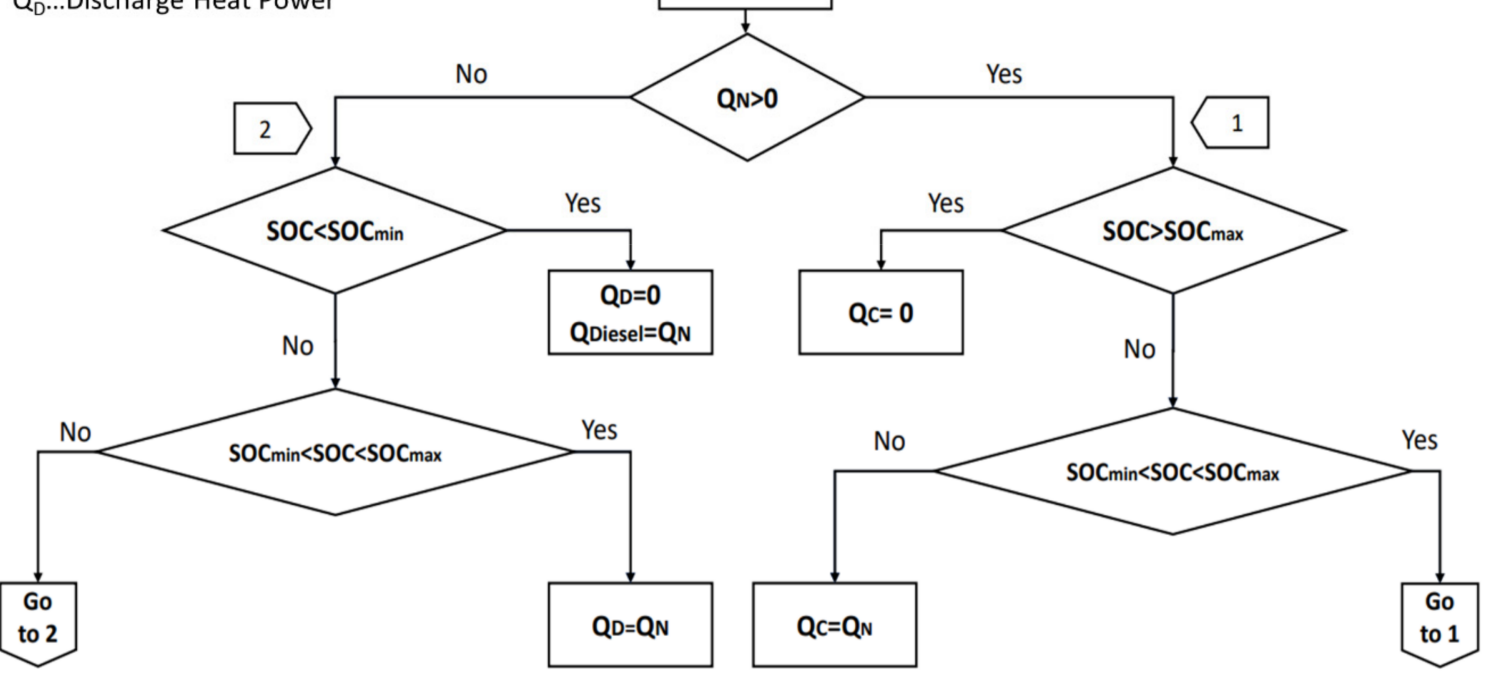

Figure 7. Flow chart of the proposed algorithm for the thermal part of the HPS controlled by the thermal storage. 
Table 7. The four different developed simulation scenarios representing the included plants in each scenario.

\begin{tabular}{cccc}
\hline & Electrical Power Source & Space Heating Source & DHW Source \\
\hline Scenario 1 & PV System & Diesel Heater & Solar Thermal System \\
(reference) & Utility Grid & Thermal Storage & Thermal Storage \\
Scenario 2 & PV System & Solar Thermal System & $\begin{array}{c}\text { Solar Thermal System } \\
\text { Thermal Storage }\end{array}$ \\
& PV System & Thermal Storage \\
Scenario 3 & Battery System & Thermal Storage & Solar Thermal System \\
& SOFC System & Thermal Storage \\
Scenario 4 & PV System & SOFC with PtG system & Solar Thermal System \\
& Battery System & Thermal Storage & Thermal Storage \\
& SOFC with PtG system & & \\
\hline
\end{tabular}

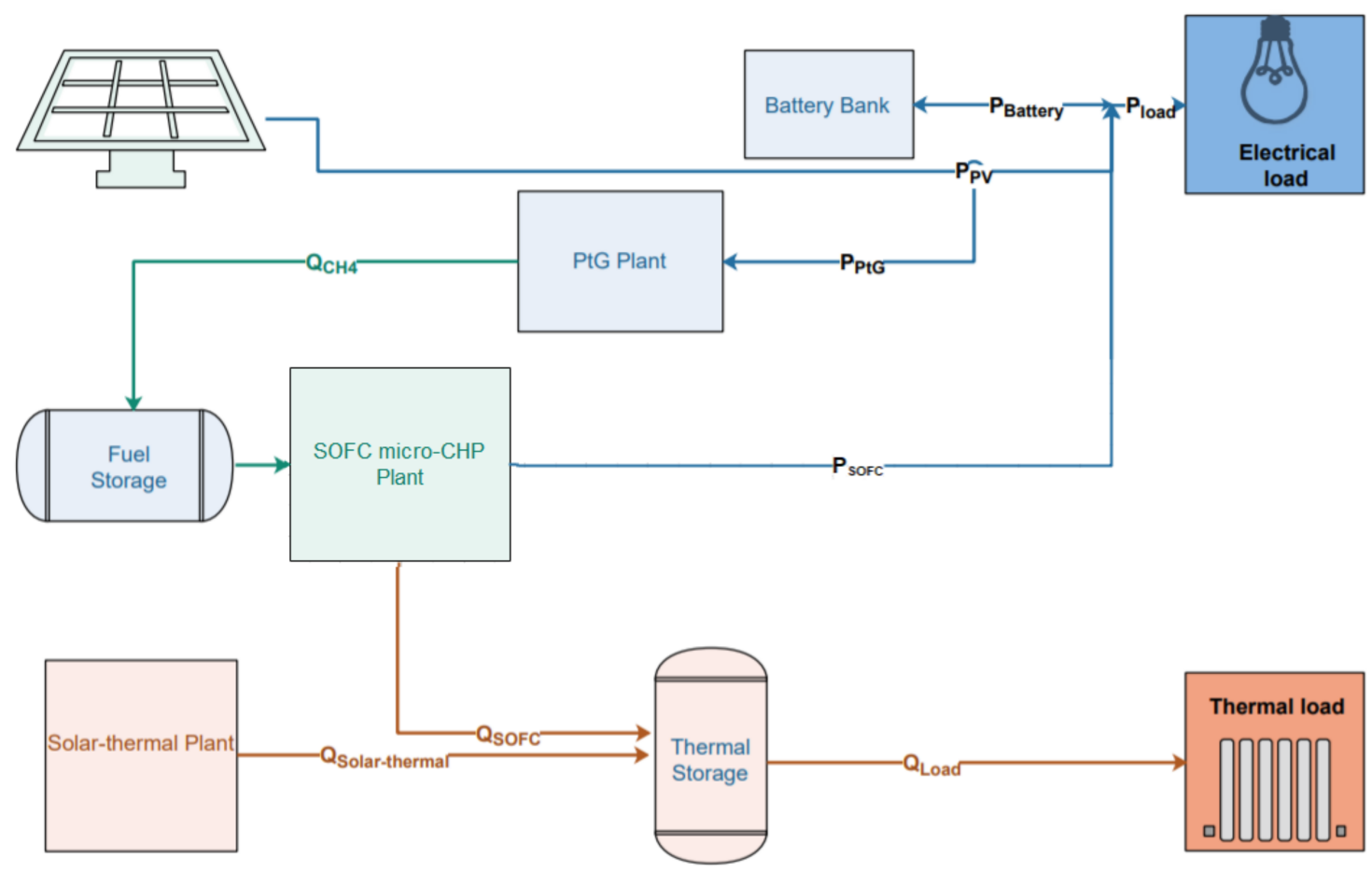

Figure 8. The HPS model with all the integrated components, Scenario 4.

Analyzing the models according to the ten day-type categories enables observation of the results for different time periods in addition to their variation with weather conditions and associated energy demand. Moreover, it helps in identifying how the HPS operates in essentially different day-type categories. The analysis of the winter day represents a high heat demand, while the summer day analysis represents a low heat demand with high electricity demand. In contrast, a full year analysis gives a design proposal that better shows the different requirements of the whole year and provides a general guideline on how the plant should operate.

\section{Analysis and Results}

In this section, the findings of the study concerning the needed dimension of plants and storages capacities, the total $\mathrm{CO}_{2}$ emissions, and the total land area of the HPS are listed.

\subsection{Energy Production}

As shown in Table 8, the primary source for serving electricity is the PV system, while the SOFC micro-CHP operates as a back-up generator. The operation of SOFC micro-CHP system is dominated by the electrical demand, while the thermal energy is a by-product; if 
needed it will be stored in the thermal storage, otherwise, it dissipates to the surroundings. The produced thermal energy by the SOFC micro-CHP system is higher than the electrical energy due to the higher thermal efficiency. The excess electrical energy produced by the PV system is consumed by the electrolyzer in order to form a useful hydrogen fuel.

Table 8. Annual energy demands and simulated annual energy productions of the PV, the SOFC system, the utility grid, the solar thermal system, the diesel heater and the electrolyzer for the different simulation scenarios.

\begin{tabular}{|c|c|c|c|c|c|c|c|}
\hline \multirow{2}{*}{$\begin{array}{l}\text { Annual } \\
\text { Demand }\end{array}$} & \multicolumn{4}{|c|}{ Electricity (kWh) } & \multicolumn{3}{|c|}{ Thermal Load (kWh) } \\
\hline & \multicolumn{4}{|c|}{8080} & \multicolumn{3}{|c|}{8926} \\
\hline $\begin{array}{c}\text { Annual } \\
\text { Production }\end{array}$ & $\begin{array}{l}\text { PV System } \\
(\mathrm{kWh} / \text { Year) }\end{array}$ & $\begin{array}{l}\text { Utility Grid } \\
(\mathrm{kWh} / \text { Year) }\end{array}$ & $\begin{array}{l}\text { SOFC Electrical } \\
(\mathbf{k W h} / \text { Year })\end{array}$ & $\begin{array}{l}\text { SOFC Thermal } \\
(\mathbf{k W h} / \text { Year) }\end{array}$ & $\begin{array}{c}\text { Solar Thermal System } \\
\text { (kWh/Year) }\end{array}$ & $\begin{array}{c}\text { Diesel Heater } \\
(\mathrm{kWh} / \text { Year })\end{array}$ & $\begin{array}{l}\text { Electrolyzer } \\
(\mathrm{kWh} / \text { Year) }\end{array}$ \\
\hline Scenario 1 & 3770 & 4300 & - & - & 3720 & 5640 & - \\
\hline Scenario 2 & 8280 & - & - & - & 30,650 & - & - \\
\hline Scenario 3 & 6020 & - & 2330 & 3520 & 21,780 & - & - \\
\hline Scenario 4 & 7540 & - & 3520 & 5130 & 21,820 & - & -2810 \\
\hline
\end{tabular}

Concerning the thermal part, the solar thermal system is the primary source for covering the thermal demand during the whole year. Due to the seasonal behavior of the solar energy, the solar thermal system produces higher thermal energy than the demand in some cases. In times of low solar power (particularly winter), a high capacity of solar thermal system is needed to ensure a full coverage for the thermal demand. This leads to a high amount of excess energy in times of high solar power (summer).

In Scenario 3, the inclusion of the SOFC micro-CHP system cancelled the need for both the diesel heater and the utility grid import.

In Scenario 3 and 4, the generated electrical energy by the SOFC system results in a needed amount of fuel of about $910 \mathrm{~kg} \mathrm{CH}_{4}$ /year and $1090 \mathrm{~kg} \mathrm{CH}_{4}$ /year, respectively. It is also noticed that the produced hydrogen by the PV system's surplus energy through the electrolyzer in Scenario 4 is about $70 \mathrm{~kg} \mathrm{H}_{2}$ /year. Accordingly, in order to produce the above-mentioned amount of hydrogen, $740 \mathrm{~L}$ of water is required per year. Additionally, the formed methane fuel through the methanation process is about $120 \mathrm{~kg} \mathrm{CH}_{4} /$ year.

\subsection{Component Dimensions and $\mathrm{CO}_{2}$ Emissions}

As an intended aim of this work, the area of the HPS should be appropriate compared to the available area of the single-family house and the total $\mathrm{CO}_{2}$ emission, and the battery capacity should be minimized as well. These criteria are satisfied in Scenario 4, according to the results listed in Table 9 and Figure 9.

Table 9. The total area in $\mathrm{m}^{2}$ for each simulation scenario according to the number of PV-panels used and the solar-thermal system area.

\begin{tabular}{ccccc}
\hline & $\begin{array}{c}\text { No. of PV Panels } \\
\text { (Parallel/Series) }\end{array}$ & $\begin{array}{c}\text { PV Panel Area } \\
\left(\mathbf{m}^{\mathbf{2}}\right)\end{array}$ & $\begin{array}{c}\text { Solar Thermal } \\
\left.\text { System Area } \mathbf{( m}^{\mathbf{2}}\right)\end{array}$ & Total Area $\left(\mathbf{m}^{\mathbf{2}}\right)$ \\
\hline Scenario 1 & $3 / 5$ & 25 & 4 & 29 \\
Scenario 2 & $3 / 11$ & 55 & 30 & 83 \\
Scenario 3 & $3 / 8$ & 40 & 21 & 61 \\
Scenario 4 & $3 / 10$ & 50 & 21 & 71 \\
\hline
\end{tabular}




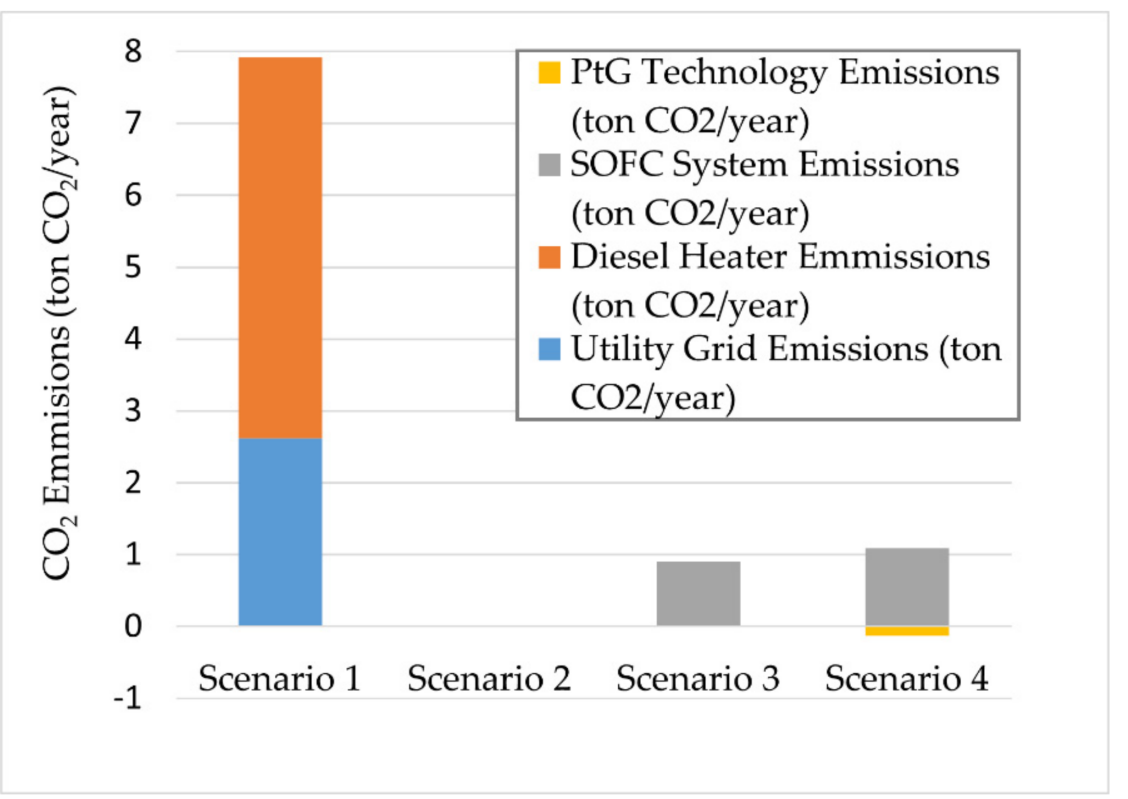

Figure 9. The total amount of the produced $\mathrm{CO}_{2}$ emissions in each scenario according to the integrated system.

Figure 9 shows the total $\mathrm{CO}_{2}$ emissions during operation for each scenario divided into the emissions caused by the utility grid, the diesel heater and the fuel cell. The effect of the diesel heater and the utility grid is noticeable when comparing the emissions in Scenario 1 to the other scenarios. The inclusion of the SOFC micro-CHP system in Scenario 3 results in a significant reduction in $\mathrm{CO}_{2}$ emissions compared to the conventional power generators (utility grid and diesel heater). Furthermore, the integration of the PtG technology in Scenario 4 offers a seasonal energy storage, which is also a $\mathrm{CO}_{2}$ sink. Summing up the $\mathrm{CO}_{2}$ source and sink gives a total emission of $0.96 \mathrm{t} \mathrm{CO}_{2} /$ year, which is slightly higher than the $\mathrm{CO}_{2}$ emission for Scenario 3 of $0.91 \mathrm{t} \mathrm{CO}_{2}$ /year.

The results obtained in Table 10 for the energy storages are based on the assumption that there are no losses to the surroundings. In Scenario 2, a huge capacity of the battery is required in order to compensate the seasonal behavior of the solar energy. As a result of adding the SOFC micro-CHP to the HPS, the needed capacity of the battery bank is reduced significantly; whereas, in Scenario 3, the SOFC compensated the seasonal behavior of the solar energy instead of the battery bank. Integrating the PtG technology with fuel storage to the HPS offers a long term and seasonal energy storage with a proper capacity compared to the battery bank. Figure 10 shows the behavior of both, the battery bank and the fuel storage, throughout the year, starting from the 1st of January.

Table 10. The needed storage capacities for the battery, the thermal storage and the fuel storage for each scenario.

\begin{tabular}{cccc}
\hline & $\begin{array}{c}\text { Battery Capacity } \\
\mathbf{( k W h )}\end{array}$ & $\begin{array}{c}\text { Thermal Storage } \\
\text { Volume }\left(\mathbf{m}^{\mathbf{3}}\right)\end{array}$ & Fuel Storage (kWh) \\
\hline Scenario 1 & - & 1.2 & - \\
Scenario 2 & 640 & 4.0 & - \\
Scenario 3 & 25 & 0.75 & - \\
Scenario 4 & 14 & 0.75 & 6 \\
\hline
\end{tabular}




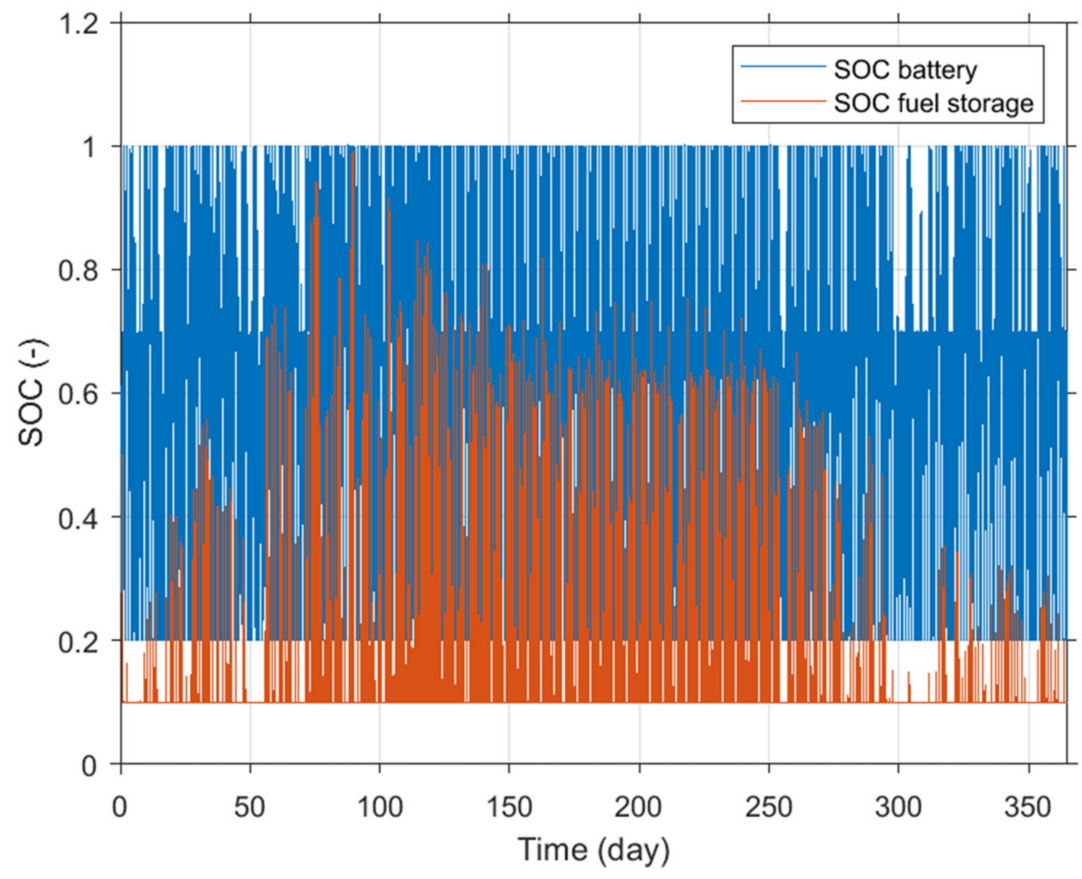

Figure 10. The seasonal behavior of the battery and the fuel storage in an annual basis starting from January in the Scenario 4.

\section{Discussion}

This study presented a HPS model for residential use analyzed in terms of the environmental benefits. Data sets for different day-type categories and weather scenarios were developed based on different configurations in order to determine the sizing characteristics and operation profiles for all the plants included in the HPS. The heat demand is covered by the solar thermal system, the fuel cell and the thermal storage, while the electricity demand is covered by the PV system, the fuel cell and the battery bank.

The importance of this study is that it takes in consideration the plant and the house as one object, which helps in optimizing the whole system. In addition, it identifies the interaction between the house and the plant, especially the SOFC micro-CHP. This led to the development of a proper controlling strategy that determines the operational time for each plant involved in the HPS for better and more efficient power generation. Using the annual simulations, the plant components can be dimensioned and the feasibility of the different scenarios can be proven.

The study showed that the HPS comprised of PV/SOFC micro-CHP provides $\mathrm{CO}_{2}$ savings of $88.6 \%$ compared to the conventional designed system. The addition of a PtG plant provides $\mathrm{CO}_{2}$ savings in the same range of $87.8 \%$. The HPS with a PtG plant and methanation process in this study has a seasonal energy storage with an acceptable capacity of fuel storage. It shows that the excess energy produced by the PV-array during summer can be stored efficiently with low losses to be used during the low PV power production in winter. This helps in reducing the needed area for the PV panels compared to Scenario 2 and the battery bank capacity. Compared to Scenario 3, the PV area is slightly increased, while the battery capacity is lower and the SOFC system has a slightly higher operational time during the year. With these design numbers, it was found that the PtG plant helps in forming $12 \%$ of the needed fuel to operate the SOFC for the residential user by capturing the excess energy from the PV system.

From the author's perspective, Scenario 3 and 4 are promising options for future residential buildings. This study makes clear that SOFC technology can help to make households grid independent. To handle the limited cycle stability, the hot standby operation is assumed. The self-sufficient energy supply for the building has the chance to unburden the electricity grid in case of unstable grid conditions (e.g., peak demands) and 
in regions with unstable grids. Residential building can also be supplied in remote areas. Assuming Scenario 3 and 4, a grid-independent power supply can be realized with limited area requirements compared to Scenario 2. The PtG technology helps to balance the strongly seasonal characteristic of renewable energies, such as the solar power in this case, with reduced battery capacities compared to Scenario $2(-98 \%)$, and also compared to Scenario 3 $(-44 \%)$. However, higher fuel inputs are required in Scenario 4 since the conversion losses of the PtG system need to be compensated. Nevertheless, the PtG technology provides the option for the production of fuel on site with the potential of being self-sufficient and independent of external fuel supply, by increasing the PV area, the battery capacity, the PtG system and the fuel storage. This option might be more and more interesting for different applications in the future.

Comparing the amounts of produced and consumed heat, in Scenario 2, 3 and 4, a high optimization potential is obvious, as more than half of the produced heat is not used. Seasonal thermal storages could be a solution to balance the differences in production and consumption, which is not considered here. Furthermore, the controlling strategy of the SOFC system might be adapted, e.g., considering heat-controlled or a combined electrical and heat-controlled operation depending on the individual scenario. Additionally, the overall interaction between the house and the plant could be optimized by sophisticated algorithms in terms of model predictive controls or others.

However, the more components are integrated in the HPS, the more Capital Expenditures (CAPEX) are added. Based on a rough estimation, the cost for the defined HPS in Scenario 4 is around $66,000 \$$. In comparison to this, equipment costs of $70,000 \$$ are expected for an HPS of Scenario 2. More costs details are presented in Table 11.

Table 11. The expected CAPEX of the HPS at each scenario in this study, in addition to the costs per each equipment. Abbreviations: Capital Expenditures (CAPEX).

\begin{tabular}{|c|c|c|c|c|c|c|}
\hline & $\begin{array}{c}\text { Total CAPEX } \\
(\$)\end{array}$ & $\begin{array}{c}\text { PV System CAPEX } \\
\left(\$ / \mathbf{k W}_{\mathbf{P}}\right)\end{array}$ & $\begin{array}{l}\text { SOFC CAPEX } \\
(\$ / \mathbf{k W})\end{array}$ & $\begin{array}{l}\text { Solar Thermal } \\
\text { CAPEX }\left(\$ / \mathrm{m}^{2}\right)\end{array}$ & $\begin{array}{c}\text { Electrolyzer } \\
\text { CAPEX }(\$ / k W)\end{array}$ & $\begin{array}{c}\text { Battery CAPEX } \\
\text { (\$/kWh) }\end{array}$ \\
\hline Scenario 1 & 11,000 & \multirow{4}{*}{740 [27] } & \multirow{4}{*}{$3000-4000$ [28] } & \multirow{4}{*}{2000} & \multirow{4}{*}{1800 [29] } & \multirow{4}{*}{ 700-1000 } \\
\hline Scenario 2 & 71,000 & & & & & \\
\hline Scenario 3 & 59,000 & & & & & \\
\hline Scenario 4 & 68,000 & & & & & \\
\hline
\end{tabular}

As a next step, detailed cost models can be developed based on the CAPEX and the OPEX, which results from the simulation, to estimate the overall cost of the different scenarios. This will also be interesting with assumed future equipment costs and subsidies, as well as future fuel and energy cost, as well costs of emissions.

In this study, the $\mathrm{CO}_{2}$ emissions during the lifetime of the components is analyzed. Additionally, a life cycle assessment (LCA) should be done for the proposed HPSs, proving the overall environmental impact over the whole life cycle, such as green house warming potential. However, solar power systems, SOFCs and PtG systems are considered as key technologies to reach the goal of a low carbon economy, by reducing $\mathrm{CO}_{2}$ emissions and limiting the production of other pollutants during operation.

Author Contributions: Conceptualization, L.N.; methodology, L.N. and M.R., software, R.S.G.; validation, R.S.G., L.N. and M.R.; formal analysis, L.N. and M.R.; investigation, R.S.G.; data curation, R.S.G.; writing-original draft preparation, R.S.G.; writing-review and editing, L.N. and M.R.; visualization, R.S.G.; supervision, L.N.; project administration, L.N. All authors have read and agreed to the published version of the manuscript.

Funding: This research received no external funding.

Institutional Review Board Statement: Not applicable.

Informed Consent Statement: Not applicable.

Conflicts of Interest: The authors declare no conflict of interest. 


\section{Nomenclature}

$\Delta \quad$ Difference

C Battery Capacity Ah

$\mathrm{c}_{\mathrm{p}} \quad$ Specific Heat

$\mathrm{E}_{\mathrm{t}} \quad$ Electricity Consumption Per Time Step

$\mathrm{kJ} / \mathrm{kg} \cdot \mathrm{k}$

$\mathrm{kW}$

ge Grid Electricity Emissions Factor

$\mathrm{Kg} \mathrm{CO}_{2} / \mathrm{kWh}$

g Natural Gas Emission Factor

$\mathrm{Kg} \mathrm{CO}_{2} / \mathrm{kWh}$

$\mathrm{G}_{\mathrm{t}} \quad$ Total Gas Consumption Per Time Step

$\mathrm{kW}$

$\mathrm{G}_{\mathrm{t}, \mathrm{DH}} \quad$ Diesel Heater Gas Consumption Per Time Step kW

$\mathrm{G}_{\mathrm{t}, \mathrm{FC}} \quad$ Fuel Cell Gas Consumption Per Time Step $\quad \mathrm{kW}$

$\mathrm{H} \quad$ Enthalpy

ISC Short Circuit Current A

k Energy Density $\mathrm{J} / \mathrm{m}^{3}$

$\mathrm{m} \quad$ Mass $\mathrm{kg}$

$m \quad$ Mass Flow Rate $\mathrm{kg} / \mathrm{s}$

$\eta \quad$ Efficiency -

NPV,Parallel Number of PV Modules Connected in Parallel

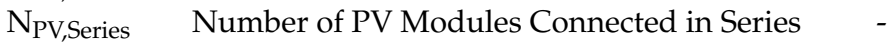

$\mathrm{P} \quad$ Electrical Power $\mathrm{kW}$

Q Heat Power kW

q Heat Energy J

$\mathrm{T}$ Temperature $\quad{ }^{\circ} \mathrm{C}$

U Cell Cell Potential V

$\mathrm{V}_{\mathrm{OC}} \quad$ Open Circuit Voltage V

$\mathrm{z} \quad \mathrm{Total} \mathrm{CO}_{2}$ Emissions $\quad \mathrm{Kg} \mathrm{CO}_{2}$

\section{Subscripts}

$\begin{array}{ll}\text { C } & \text { Charging } \\ \text { D } & \text { Discharging } \\ \text { DC } & \text { Direct Current } \\ \text { DH } & \text { Diesel Heater } \\ \text { elec } & \text { Electrical } \\ \text { EZ } & \text { Electrolyzer } \\ \text { FC } & \text { Fuel Cell } \\ \mathrm{G} & \text { Grid } \\ \text { L } & \text { Load } \\ \text { max } & \text { Maximum } \\ \text { min } & \text { Minimum } \\ \mathrm{N} & \text { Net } \\ \mathrm{P} & \text { Production } \\ \mathrm{t} & \text { Time step } \\ \text { ther } & \text { Thermal }\end{array}$

\section{Abbreviations}

CAPEX Capital Expenditures

$\mathrm{CH}_{4} \quad$ Methane

CHP Combined Heat and Power

$\mathrm{CO} \quad$ Carbon monoxide

$\mathrm{CO}_{2} \quad$ Carbon dioxide

DC Direct Current

DHW Domestic Hot Water

DOD Depth of Discharge

FC Fuel Cell

$\mathrm{H}_{2} \quad$ Hydrogen 


\begin{tabular}{|c|c|}
\hline $\mathrm{H}_{2} \mathrm{O}$ & Water \\
\hline $\mathrm{HHV}$ & Higher Heating Value \\
\hline HPS & Hybrid Power System \\
\hline LCA & Life Cycle Assessment \\
\hline LHV & Lower Heating Value \\
\hline MPP & Maximum Power Point \\
\hline NG & Natural Gas \\
\hline $\mathrm{NO}_{X}$ & Nitrogen oxides \\
\hline OPEX & Operational Cost \\
\hline PEM & Polymer Electrolyte Membrane \\
\hline PEME & Polymer Electrolyte Membrane Electrolyzer \\
\hline PtG & Power to Gas \\
\hline PV & Photovoltaic \\
\hline PVGIS & Photovoltaic Geographical Information System \\
\hline rSOC & Reversible Solid Oxide Cell \\
\hline SHX & Summer Holiday day type \\
\hline SNG & Substitute Natural Gas \\
\hline SOC & State of Charge \\
\hline SOFC & Solid Oxide Fuel Cell \\
\hline $\mathrm{SO}_{\mathrm{X}}$ & Sulfur oxides \\
\hline SWX & Summer Working day type \\
\hline THC & Transition Holiday Cloudy day type \\
\hline THS & Transition Holiday Sunny day type \\
\hline TWC & Transition Working Cloudy day type \\
\hline TWS & Transition Working Sunny day type \\
\hline VDI & Verein Deutscher Ingenieure \\
\hline WHC & Winter Holiday Cloudy day type \\
\hline WHS & Winter Holiday Sunny day type \\
\hline WWC & Winter Working Cloudy day type \\
\hline WWS & Winter Working Sunny day type \\
\hline
\end{tabular}

\section{References}

1. Tuyen, N.D.; Fujita, G.; Duc, N.; Fujit, G. Modelling a SOFC Power Unit Using Natural Gas Fed Directly: 20. In Advances in Natural Gas Technology; Al-Megren, H., Ed.; IntechOpen: Rijeka, Croatia, 2012.

2. Naimaster, E.J., IV; Sleiti, A.K. Potential of SOFC CHP systems for energy-efficient commercial buildings. Energy Build. 2013, 61, 153-160. [CrossRef]

3. Zhang, L.; Xing, Y.; Xu, H.; Wang, H.; Zhong, J.; Xuan, J. Comparative study of solid oxide fuel cell combined heat and power system with Multi-Stage Exhaust Chemical Energy Recycling: Modeling, experiment and optimization. Energy Convers. Manag. 2017, 139, 79-88. [CrossRef]

4. Ellamla, H.R.; Staffell, I.; Bujlo, P.; Pollet, B.G.; Pasupathi, S. Current status of fuel cell based combined heat and power systems for residential sector. J. Power Sources 2015, 293, 312-328. [CrossRef]

5. Adam, A.; Fraga, E.S.; Brett, D.J. Modelling and Optimisation in Terms of $\mathrm{CO}_{2}$ Emissions of a Solid Oxide Fuel Cell based Micro-CHP System in a Four Bedroom House in London. Energy Procedia 2013, 42, 201-209. [CrossRef]

6. Frenzel, I.; Loukou, A.; Trimis, D.; Schroeter, F.; Mir, L.; Marin, R.; Egilegor, B.; Manzanedo, J.; Raju, G.; De Bruijne, M.; et al. Development of an SOFC based Micro-CHP System in the Framework of the European Project FC-DISTRICT. Energy Procedia 2012, 28, 170-181. [CrossRef]

7. Shimoda, Y.; Taniguchi-Matsuoka, A.; Inoue, T.; Otsuki, M.; Yamaguchi, Y. Residential energy end-use model as evaluation tool for residential micro-generation. Appl. Therm. Eng. 2017, 114, 1433-1442. [CrossRef]

8. Sadeghi, S.; Ameri, M. Comparison of different power generators in PV-battery-power generator hybrid system. J. Mech. Sci. Technol. 2014, 28, 387-398. [CrossRef]

9. Nousch, L.; Hartmann, M.; Michaelis, A. Improvements of Micro-CHP SOFC System Operation by Efficient Dynamic Simulation Methods. Processes 2021, 9, 1113. [CrossRef]

10. Hanasaki, M.; Uryu, C.; Daio, T.; Kawabata, T.; Tachikawa, Y.; Lyth, S.M.; Shiratori, Y.; Taniguchi, S.; Sasaki, K. SOFC Durability against Standby and Shutdown Cycling. J. Electrochem. Soc. 2014, 161, F850-F860. [CrossRef]

11. Xiao-Long, W.; Yuanwu, X.; Tao, X.; Dongqi, Z.; Jianhua, J.; Zhonghua, D.; Xiaowei, F.; Xi, L. Standby and Shutdown Cycles Modeling of SOFC Lifetime Prediction. Energy Procedia 2019, 158, 1573-1578. [CrossRef] 
12. Wu, X.-L.; Xu, Y.-W.; Xue, T.; Zhao, D.-Q.; Jiang, J.; Deng, Z.; Fu, X.; Li, X. Health state prediction and analysis of SOFC system based on the data-driven entire stage experiment. Appl. Energy 2019, 248, 126-140. [CrossRef]

13. Götz, M.; Lefebvre, J.; Mörs, F.; McDaniel Koch, A.; Graf, F.; Bajohr, S.; Reimert, R.; Kolb, T. Renewable Power-to-Gas: A technological and economic review. Renew. Energy 2016, 85, 1371-1390. [CrossRef]

14. Tietze, V.; Stolten, D. Comparison of hydrogen and methane storage by means of a thermodynamic analysis. Int. J. Hydrogen Energy 2015, 40, 11530-11537. [CrossRef]

15. Haddad, A.; Ramadan, M.; Khaled, M.; Ramadan, H.; Becherif, M. Study of hybrid energy system coupling fuel cell, solar thermal system and photovoltaic cell. Int. J. Hydrogen Energy 2018, 45, 13564-13574. [CrossRef]

16. Ghenai, C.; Bettayeb, M. Modelling and performance analysis of a stand-alone hybrid solar PV/Fuel Cell/Diesel Generator power system for university building. Energy 2019, 171, 180-189. [CrossRef]

17. Lokar, J.; Virtič, P. The potential for integration of hydrogen for complete energy self-sufficiency in residential buildings with photovoltaic and battery storage systems. Int. J. Hydrogen Energy 2020, 45, 34566-34578. [CrossRef]

18. Hosseini, M.; Dincer, I.; Rosen, M.A. Hybrid solar-fuel cell combined heat and power systems for residential applications: Energy and exergy analyses. J. Power Sources 2012, 221, 372-380. [CrossRef]

19. VDI. Reference Load Profiles of Single-Family and Multi-Family Houses for the Use of CHP Systems VDI-4655; Beuth: Berlin, Germany, 2008.

20. European Commission, Joint Research Centre Photovoltaic Geographical Information System (PVGIS). Available online: https: / / ec.europa.eu/jrc/en/pvgis (accessed on 4 May 2020).

21. Fritzson, P. Introduction to Modeling and Simulation of Technical and Physical Systems with Modelica; John Wiley \& Sons: Hoboken, NJ, USA, 2011. [CrossRef]

22. Scheepers, F.; Stähler, M.; Stähler, A.; Rauls, E.; Müller, M.; Carmo, M.; Lehnert, W. Improving the Efficiency of PEM Electrolyzers through Membrane-Specific Pressure Optimization. Energies 2020, 13, 612. [CrossRef]

23. Ghenai, C.; Bettayeb, M.; Brdjanin, B.; Hamid, A.K. Hybrid solar PV/PEM fuel Cell/Diesel Generator power system for cruise ship: A case study in Stockholm, Sweden. Case Stud. Therm. Eng. 2019, 14, 100497. [CrossRef]

24. Kosonen, A.; Koponen, J.; Huoman, K.; Ahola, J.; Ruuskanen, V.; Ahonen, T.; Graf, T. Optimization strategies of PEM electrolyser as part of solar PV system. In Proceedings of the 2016 18th European Conference on Power Electronics and Applications (EPE'16 ECCE Europe), Karlsruhe, Germany, 5-9 September 2016; pp. 1-10. [CrossRef]

25. Sarbu, I.; Sebarchievici, C. A Comprehensive Review of Thermal Energy Storage. Sustainability 2018, 10, 191. [CrossRef]

26. Chettibi, N.; Mellit, A. Intelligent control strategy for a grid connected PV/SOFC/BESS energy generation system. Energy 2018, 147, 239-262. [CrossRef]

27. Hilpert, S.; Dettner, F.; Al-Salaymeh, A. Analysis of Cost-Optimal Renewable Energy Expansion for the Near-Term Jordanian Electricity System. Sustainability 2020, 12, 9339. [CrossRef]

28. Cigolotti, V.; Genovese, M.; Fragiacomo, P. Comprehensive Review on Fuel Cell Technology for Stationary Applications as Sustainable and Efficient Poly-Generation Energy Systems. Energies 2021, 14, 4963. [CrossRef]

29. Kreidelmeyer, S. Kosten und Transformationspfade für Strombasierte Energieträger: Studie im Auftrag des Bundesministeriums für Wirtschaft und Energie; BMWI: Berlin, Germany, 2020. 